\title{
JAPAN/EAST SEA WATER MASSES AND THEIR RELATION TO THE SEA'S CIRCULATION
}

BY LYNNE D. TALLEY, DONG-HA MIN, VYACHESLAVB. LOBANOV,

VLADIMIR A. LUCHIN, VLADIMIR I. PONOMAREV, ANATOLY N. SALYUK, ANDREY Y. SHCHERBINA, PAVEL Y. TISHCHENKO, AND IGOR ZHABIN

The Japan/East Sea is a major anomaly in the ventilation and overturn picture of the Pacific Ocean. The North Pacific is well known to be nearly unventilated at intermediate and abyssal depths, reflected in low oxygen concentration at $1000 \mathrm{~m}$ (Figure 1). (High oxygen indicates newer water in more recent contact with the atmosphere. Oxygen declines as water "ages" after it leaves the sea surface mainly because of bacterial respiration.) Even the small production of North Pacific Intermediate Water in the Okhotsk Sea (Talley, 1991; Shcherbina et al., 2003) and the tiny amount of new bottom water encountered in the deep Bering Sea (Warner and Roden, 1995) have no obvious impact on the overall oxygen distribution at $1000 \mathrm{~m}$ and below, down to $3500 \mathrm{~m}$, which is the approximate maximum depth of the Bering, Okhotsk, and Japan/East Seas.

In contrast, the nearly isolated Japan/East Sea is very well ventilated at all depths from the surface to the bottom. Oxygen is higher than anywhere else in the Pacific, even in the South Pacific, where intermediate-layer ventilation yields relatively high oxygen content at $1000 \mathrm{dbar}$ (roughly 1000-m depth). It is necessary to look much farther away, to the North Atlantic and best-ventilated sectors of the Antarctic, to find deep ventilation comparable to the Japan/East Sea's.

Because it is ventilated from top to bottom and located at mid-latitude, the Japan/East Sea has many similarities to the North Atlantic Ocean (e.g., Riser and Jacobs, 2005; Min and Warner, 2005). Both have (1) inflow of warm, saline surface waters from the south; (2) subduction that ventilates the upper ocean in the subtropics; (3) subtropical mode waters; (4) a subpolar front south of which a low-salinity water mass is formed; (5) cooling and precipitation that cause a colder, fresher subpolar north; (6) subpolar mode waters with comparable winter mixed-layer thicknesses; and (7) deep convection and ice formation that ventilate the entire water column.

The Japan/East Sea differs from the North Atlantic in two major respects: (1) the powerful northward eastern boundary current in the Japan/East Sea, the Tsushima Warm Current, distorts the subtropical gyre, and (2) the Japan/East Sea is isolated from all subsurface waters in the North Pacific. Therefore, the Japan/East Sea's salinity is nearly uniform below the shallow sill depth $(140 \mathrm{~m})$ of Tsushima Strait. The Japan/East Sea has a full temperature range, however, because surface waters cool to freezing and some of this very cold water becomes bottom water. In its isolation, the Japan/East Sea most closely resembles the Mediterranean Sea-both seas form dense water as a result of convection during winter cold-air outbreaks (Talley et al., 2003; Marshall and Schott, 1999). 


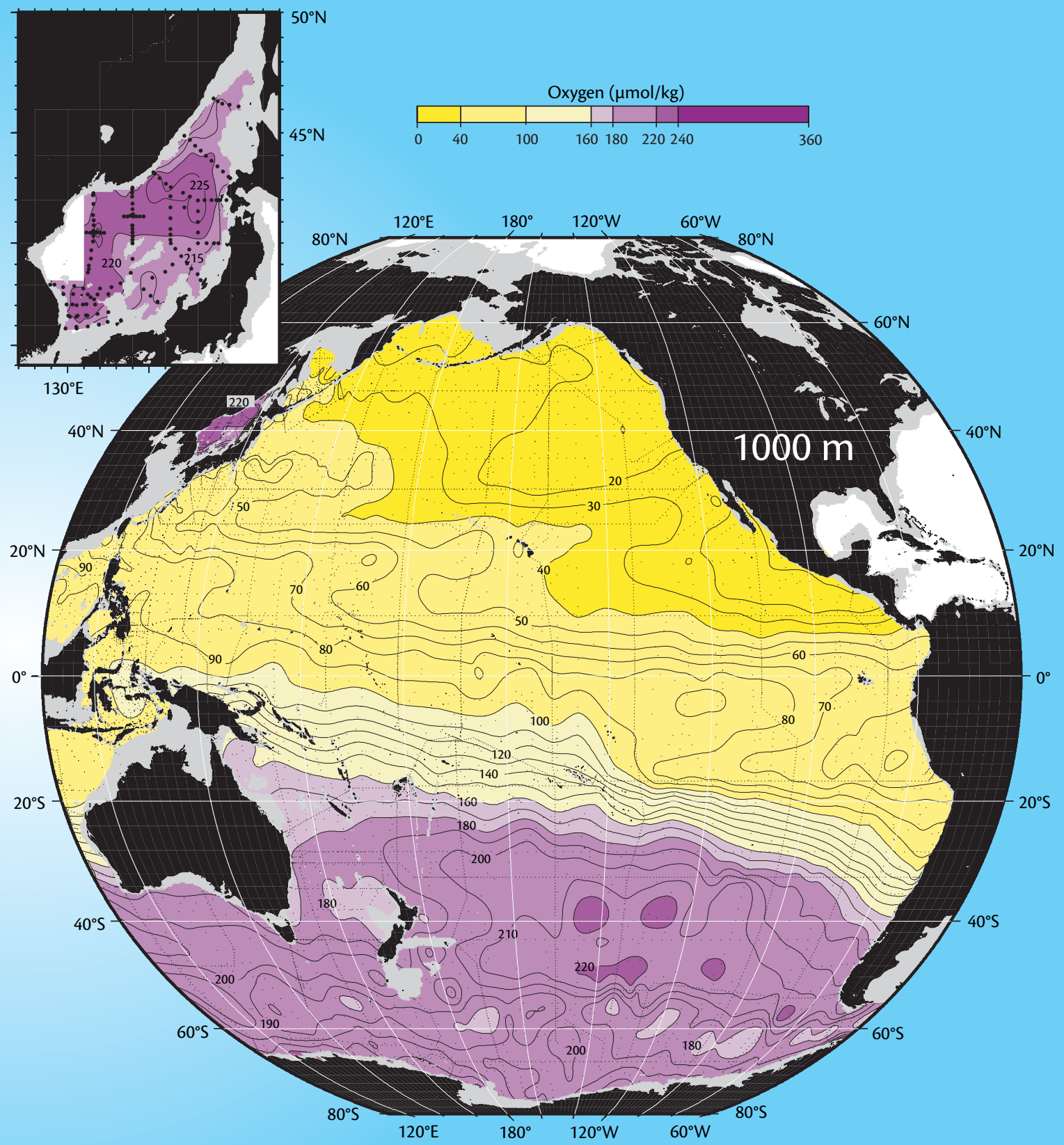

Figure 1. Oxygen ( $\mu \mathrm{mol} \mathrm{kg}^{-1}$ ) at $1000 \mathrm{~m}$ for the Pacific Ocean and Japan/East Sea (inset with higher horizontal resolution) (after Talley, 2006 and Talley et al., 2004). High oxygen (purple) indicates more recent ventilation (penetration of surface waters). The Japan/East Sea stands out as a place of very high ventilation at depth, much higher than anywhere else in the Pacific including the Antarctic. This map is representative of the situation to the bottom of the Japan/East Sea, at about 3500-m depth. Data are from the World Ocean Circulation Experiment, the National Oceanographic Data Center, the summer 1999 survey on the R/V Revelle and R/V Professor Khromov in the Japan/East Sea, and a 2000 data set in the Okhotsk Sea. 
Throughout the water column, the Japan/East Sea can overturn quickly, on the order of decades. This is truly a region in flux; a steady-state view of deep properties in the Japan/East Sea provides faulty insight into its processes. Effects of changing surface properties can be carried to great depth on a decadal time scale; therefore, water masses are best defined based on formation processes rather than density ranges, just as in the North Atlantic Ocean.

With a mass exchange with the North Pacific Ocean on the order of $2.5 \mathrm{~Sv}$ through Tsushima Strait (Isobe et al., 2002) and a total volume of $1680 \times 10^{12} \mathrm{~m}^{3}$ (Postlethwaite et al., 2005), the average residence time of water in the Japan/East Sea is on the order of 20 years. The residence time for the intermediate and deep waters is estimated at 50 to 100 years, depending on whether epochs of higher or lower deep ventilation have been modeled (e.g., Kim and Kim, 1996; Kang et al., 2003; Postlethwaite et al., 2005).

The Japan/East Sea's high deep oxygen content has been decreasing steadily since the 1930s (Gamo et al., 1986; Kim et al., 1999, 2001; Talley et al., 2003). The presence of chlorofluorocarbons from top to bottom in the Japan/East Sea shows that renewal has occurred during the past 50 years, despite the lack of large bottom-water-formation events (Min and Warner, 2005). The decreasing deep oxygen indicates that bottom-water formation had slowed so much that oxygen penetration from the surface was overcompensated by biological consumption.

Deep and bottom waters in the Japan/ East Sea are formed by convection and brine rejection due to sea-ice formation, respectively. We observed both processes directly during our winter 1999-2000 and winter 2000-2001 surveys (Talley et al., 2003). Oxygen isotope data collected in summer 1999 also confirmed these separate sources of deep waters (Postlethwaite et al., 2005). The densest and deepest (500 to $1200 \mathrm{~m}$ ) openocean convection that we observed was south of Peter the Great Bay, in open water close to the westernmost of the anticyclonic eddies shown schematically in Figure 2. The densest brine-enriched water was formed in the ice-covered Peter the Great Bay. In fact, the very severe winter of 2001 resulted in so much brine rejection that a large amount of bottom water was formed (Kim et al., 2002; Senjyu et al., 2002; Talley et al., 2003). This bottom-water formation disrupted the deep temperature, salinity, and oxygen structures that had been relatively smooth for many decades, suggesting that major events of deep and bottom ventilation are sporadic and can be separated by more than several decades.

Observations from hydrographic

Lynne D. Talley (Italley@ucsd.edu) is Professor, Scripps Institution of Oceanography, University of California, San Diego, La Jolla, CA, USA. Dong-Ha Min is Assistant Professor, Marine Science Institute, University of Texas at Austin, Port Aransas, TX, USA. Vyacheslav B.

Lobanov is Deputy Director, V.I. Il'ichev Pacific Oceanological Institute, Far Eastern Branch, Russian Academy of Sciences, Vladivostok, Russia. Vladimir A. Luchin is Leading Research Scientist, V.I. Il'ichev Pacific Oceanological Institute, Far Eastern Branch, Russian Academy of Sciences, Vladivostok, Russia. Vladimir I. Ponomarev is Leading Research Scientist, V.I. Il'ichev Pacific Oceanological Institute, Far Eastern Branch, Russian Academy of Sciences, Vladivostok, Russia. Anatoly N. Salyuk is Leading Research Scientist, V.I. Il'ichev Pacific Oceanological Institute, Far Eastern Branch, Russian Academy of Sciences, Vladivostok, Russia. Andrey Y. Shcherbina is Postdoctoral Investigator, Woods Hole Oceanographic Institution, Woods Hole, MA, USA. Pavel Y. Tishchenko is Head, Laboratory of Hydrochemistry, V.I. Il'ichev Pacific Oceanological Institute, Far Eastern Branch, Russian Academy of Sciences, Vladivostok, Russia. Igor Zhabin is Leading Research Scientist, V.I. Il'ichev Pacific Oceanological Institute, Far Eastern Branch, Russian Academy of Sciences, Vladivostok, Russia. 


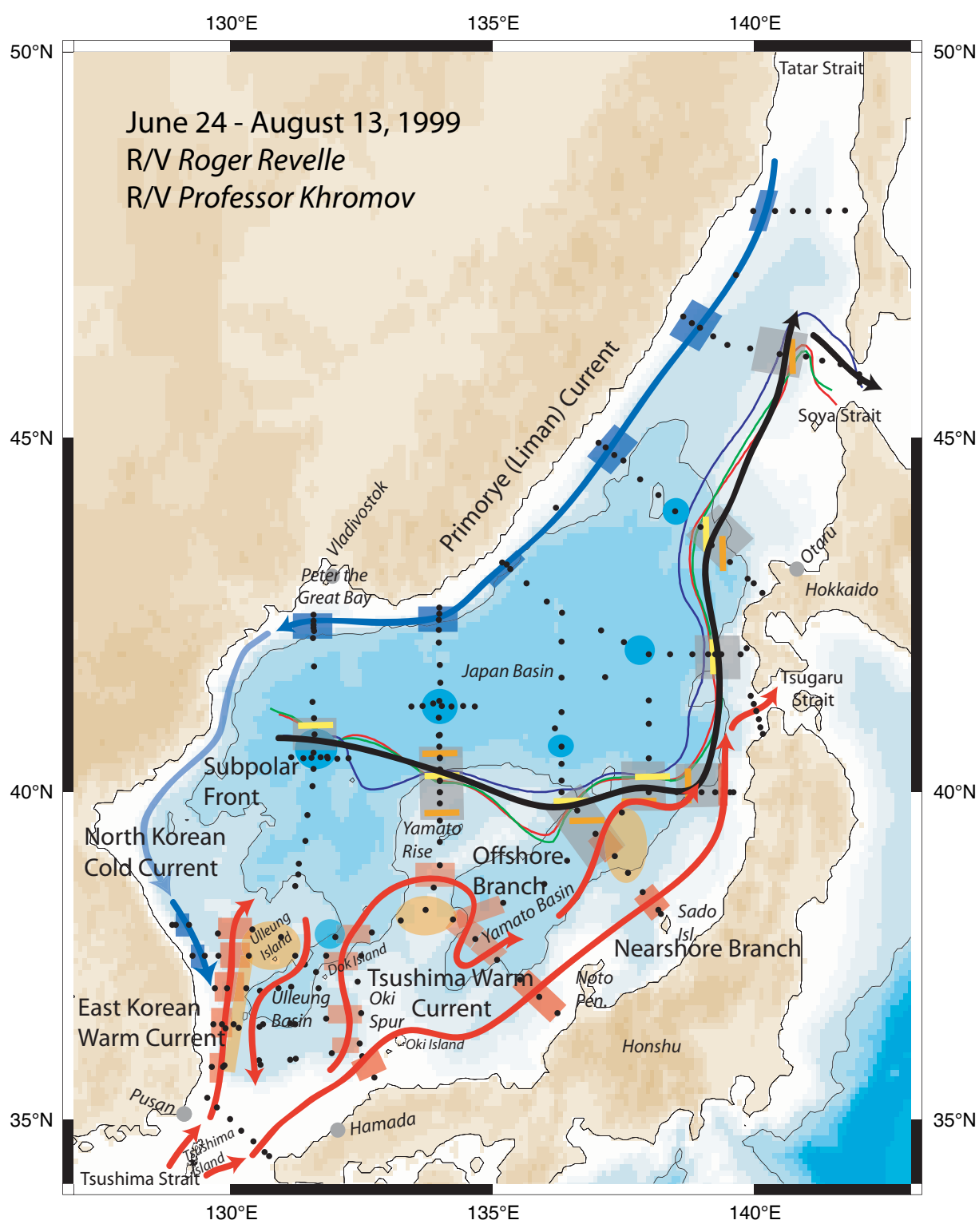

Figure 2. Major currents, fronts, and eddies of the summer 1999 hydrographic survey carried out on the R/V Revelle and R/V Professor Khromov, with the 2000-m isobath. The curves with arrows (Tsushima Warm Current and East Korean Warm Current $=$ red; Subpolar Front = black; Primorye Current and North Korean Cold Current $=$ blue) and the eddies (orange and teal) are schematics based on directly measured currents and on geostrophic velocities and transports. The small rectangles show where these currents were actually found in the data sets. Within the Subpolar Front, the yellow bars show the salinity front; the orange bars indicate the maximum velocities. The Subpolar Front is also well marked by properties such as potential temperature, potential density, and nutrients. Examples from $50 \mathrm{dbar}$ are shown here: potential temperature of $8^{\circ} \mathrm{C}$ (thin red line), potential density of $26.5 \mathrm{~kg} \mathrm{~m}^{-3}$ (thin green line), and phosphate of $0.6 \mu \mathrm{mol} \mathrm{kg}^{-1}$ (thin blue line) (see Figure 4). The orange ellipses are intrathermocline eddies of $8^{\circ} \mathrm{C}$ to $11^{\circ} \mathrm{C}$. The teal blue ellipses are anticyclonic eddies in the subpolar region that reach between $2000 \mathrm{~m}$ and the bottom. The blue ellipse at the Ulleung Basin entrance is the Dok Cold Eddy.

Table 1. Hydrographic Cruises

\begin{tabular}{|l|l|l|l|l|}
\hline Ship & $\begin{array}{l}\text { Cruise } \\
\text { Designation }\end{array}$ & Dates & Ports & $\begin{array}{l}\text { \# of } \\
\text { Stations }\end{array}$ \\
\hline R/V Roger Revelle & HNRO7 & June 14-July 17, 1999 & Pusan, Korea & 113 \\
\hline R/V Professor Khromov & KH36 & July 22-August 13, 1999 & $\begin{array}{l}\text { Vladivostok, Russia; } \\
\text { Pusan, Korea }\end{array}$ & 90 \\
\hline R/V Professor Khromov & KH38 & February 2-March 17, 2000 & $\begin{array}{l}\text { Vladivostok, Russia; } \\
\text { Otaru, Japan }\end{array}$ & 81 \\
\hline R/V Professor Khromov & KH42 & February 24-March 3, 2001 & Vladivostok, Russia & 43 \\
\hline
\end{tabular}



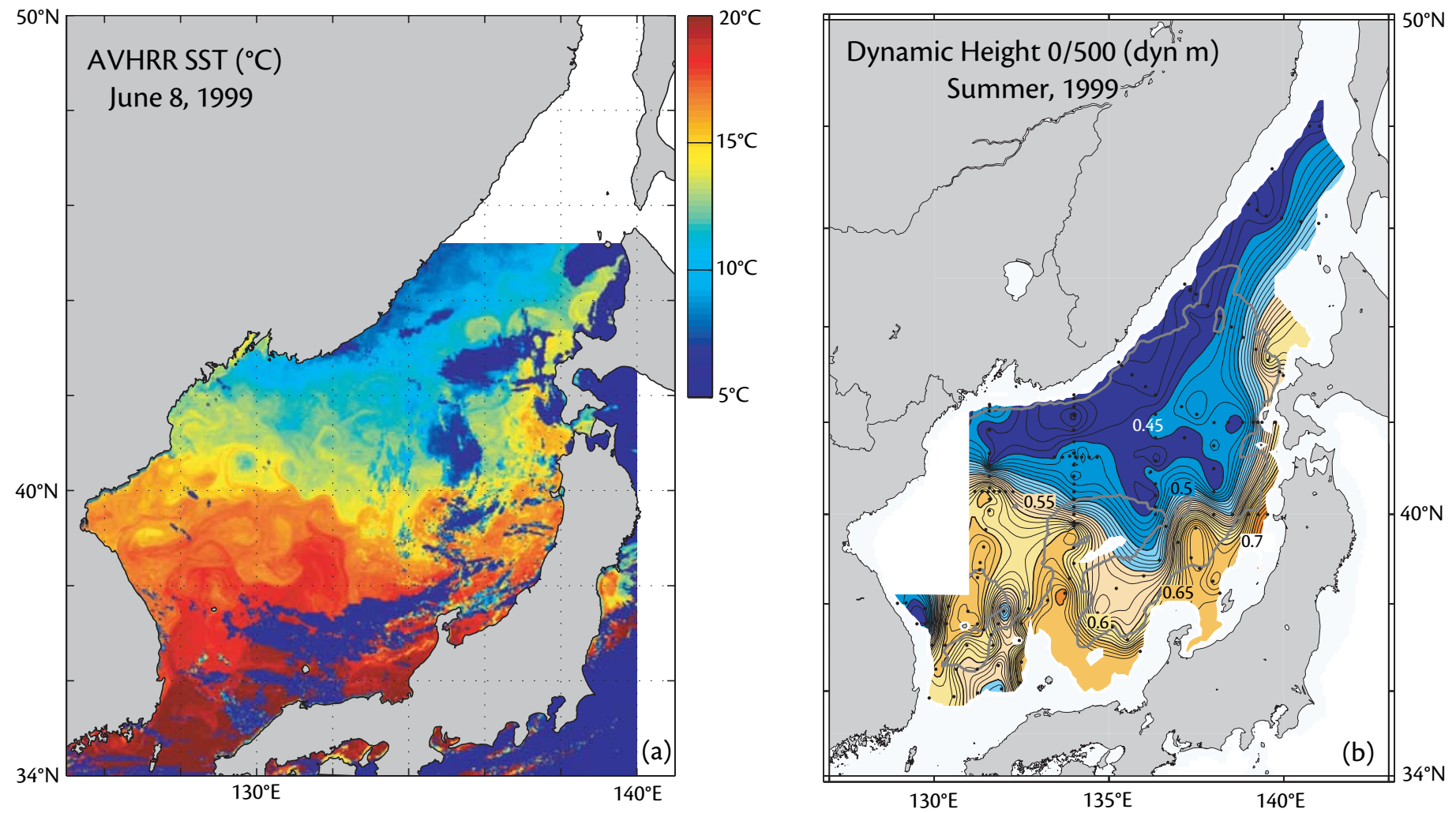

Figure 3. (a) Satellite (AVHRR) sea surface temperature $\left({ }^{\circ} \mathrm{C}\right.$ ) for June 8, 1999 (Shcherbina et al., 2003). Warmest waters enter from the south through Tsushima Strait and can be seen in the East Korean Warm Current and both branches of the Tsushima Warm Current (see Figure 2). The warm waters penetrate far to the north along the eastern boundary. The cold Liman Current is apparent in the north along the coast of Russia. (Dark blue areas are clouds.) The Subpolar Front is located at the high contrast between reds and and blues. The clockwise swirl of orange at about $41^{\circ} \mathrm{N}, 129^{\circ} \mathrm{E}$ is one of the eddies sampled in our survey (see Figure 2). (b) Dynamic height (dyn $\mathrm{m}$ ) at the sea surface relative to $500 \mathrm{dbar}$. This map roughly corresponds to sea surface height and therefore to the distribution of high and low pressure that drives the geostrophic currents (at $90^{\circ}$ to the right of the pressure gradient force). It is based on the density profile data collected on the summer 1999 cruises. The schematic currents in Figure 2 were based in part on this map. There is nice coincidence between the regions of high dynamic topography and warm sea surface temperature. The gray contour is the 2000-m isobath.

impact water-mass structures are the strait inflows and outflows, major currents (including the western and eastern boundary currents), the Subpolar Front, and vigorous eddies. Subtropical circulation, south of the Subpolar Front, is somewhat anticyclonic, but it is overwhelmed by the northeastward flow of the Tsushima Warm Current.

Mass exchange between the Japan/ East Sea and the Pacific Ocean and Okhotsk Sea is small. Inflow through Tsushima Strait is estimated from direct current measurements to be 2.2-2.7 Sv (Isobe et al., 2002; Chang et al., 2004; Teague et al., 2005a). Outflow through Tsugaru Strait is half or more of the total outflow and is estimated to be $1.4 \mathrm{~Sv}$, also from direct current observations (Shikama, 1994). Outflow through Soya Strait to the Okhotsk Sea is estimated to be 0.7-1.4 Sv (Aota and Yamada, 1990; Chu et al., 2001). Inflow through Tatar Strait is negligible, from $0.001-0.2 \mathrm{~Sv}$ (Yanagi, 2002; Chu et al., 2001), although the freshwater input from the Amur
River from this strait is important for salinity balances in the Japan/East Sea. Tsushima and Soya Strait transports have large seasonal variation, while Tsugaru Strait seasonal variation is weak.

The inflow through Tsushima Strait splits into three parts (Figure 2): (1) the East Korean Warm Current, which is the subtropical western boundary current, (2) the Nearshore Branch of the Tsushima Warm Current, which follows the coastline of Honshu as an eastern boundary current, and (3) the Offshore 
Figure 4. Properties at $50 \mathrm{dbar}$ in summer 1999 (from Talley et al., 2004 supplementary materials). This depth represents the layer slightly below the sea surface. (The actual sea-surface properties are strongly affected by local heating/cooling and evaporation/precipitation, and by biological organisms that nearly completely deplete the nutrients such as nitrate.) At $50 \mathrm{dbar}$, the contrast across the Subpolar Front between the warm, salty, lower-nutrient subtropics and the cold, fresh, higher-nutrient subpolar region is clear. (a) The potential temperature contrast is very high, a $16^{\circ} \mathrm{C}$ difference between the two regions. The cold North Korean Cold Current and the Dok Cold Eddy in the southwest (Ulleung Basin) stand out, as does the northward tongue of warm water at $133^{\circ}-135^{\circ} \mathrm{E}$ on top of Yamato Rise, following the Offshore Branch of the Tsushima Warm Current. (b) The high salinity in the subtropics has a larger range than the nearly uniform, lower salinity in the subpolar region. (c) Potential-density patterns are similar to potential-temperature patterns. (d) and (f) Oxygen and chlorofluorocarbon11 both have low concentrations in the subtropics and high concentrations in the subpolar region; this pattern is mostly due to the temperature, which affects gas solubility (warm water holds less gas). (e) Nitrate represents the other nutrients, and is low in the inflowing water from Tsushima Strait and throughout the subtropical region, and high in the subpolar waters, which include the North Korean Cold Current along the coast of Korea. High values are due to upwelling.

Branch of the Tsushima Warm Current. The Offshore Branch is a major front in water properties, separating the highest salinity of the Tsushima Warm Water to the east from structures dominated by the low-salinity East Sea Intermediate Water to the west (see section on Water Masses below).

The Primorye (or Liman) Current and North Korean Cold Current are subpolar western boundary currents carrying cold, fresh waters southward. The North Korean Cold Current and the
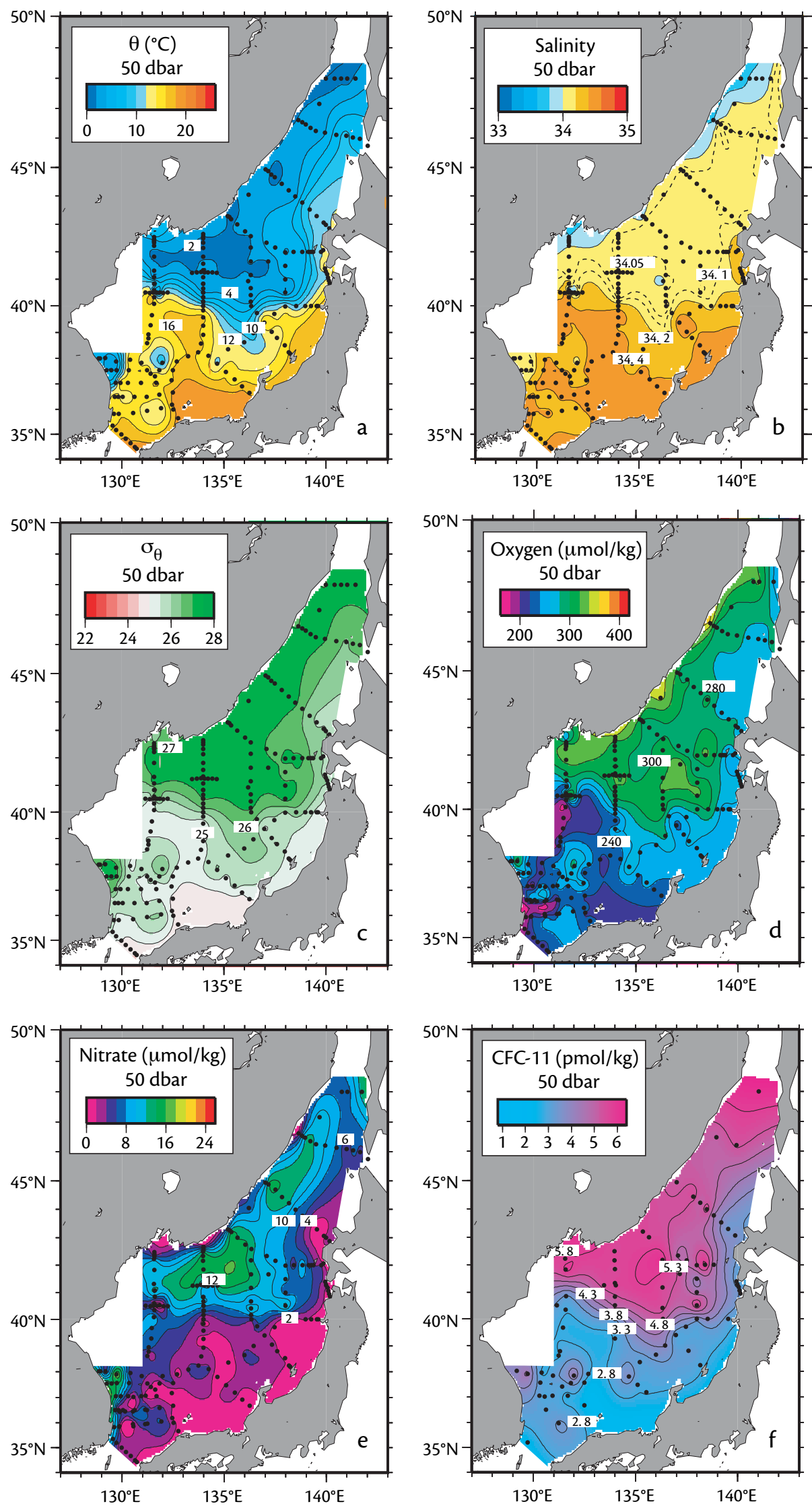
East Korean Warm Current meet along the coast of Korea. Some of the denser water in the North Korean Cold Current intrudes along the coast below the surface part of the East Korean Warm Current. Thus, some subpolar water can be transported all the way south to Tsushima Strait, as seen in many data sets including ours.

The Subpolar Front is a zonal current crossing the Japan/East Sea at about $40^{\circ} \mathrm{N}$. It then turns northward at the eastern boundary as it is joined by the warm water of the Tsushima Current. In addition to being a strong current (geostrophic speeds up to $45 \mathrm{~cm} \mathrm{sec}^{-1}$ relative to $1000 \mathrm{dbar}$ ), the Subpolar Front is a major water-mass boundary, dividing the Japan/East Sea into subtropical and subpolar regimes (Figure 4). North of the front, salinity and temperature are low, while potential density and nutrients are high. High oxygen and chlorofluorocarbon concentrations north of the front are due to cold temperatures there; oxygen saturation on the other hand is low ( $<90$ percent), which along with the high nutrient content likely indicates upwelling. The Subpolar Front can even be tracked with contours of nutrients (e.g., phosphate of $0.6 \mu \mathrm{mol} \mathrm{kg}{ }^{-1}$ at 50 dbar, shown in Figure 2).

Subtropical circulation, south of the Subpolar Front, is somewhat anticyclonic, but is overwhelmed by the northeastward flow of the Tsushima Warm Current. Subpolar circulation, north of the front, is cyclonic. The coldest, densest surface waters occur in the western subpolar region south of Vladivostok, rather than in the northernmost subpolar gyre (Tatar Strait), because of this cyclonic circulation and cumulative heat loss along the cyclonic path.

All of the currents in the Japan/East Sea are surface-intensified with weak vertical shear below the maximum strait sill depths of 150 to $200 \mathrm{~m}$. But, this does not mean that the geostrophic currents vanish at depth. Indeed, the upper-ocean currents appear to be steered by much deeper topography in many places. For instance, the Subpolar Front approximately follows the 2500-dbar contour once it reaches the northern flank of Yamato Rise after crossing the Japan Basin from the western boundary. The Offshore Branch of the Tsushima Current follows Oki Spur and Yamato Rise and is apparently affected by the topography offshore of Noto Peninsula, northeast of which it meanders. This flow pattern means that at least some part of the currents extends to the bottom.

Vigorous eddies (orange and blue ellipses in Figure 2), most extending to the ocean bottom, are important sites for water-mass transformation. In the Ulleung Basin, the well-described Ulleung Warm Eddy and the "Dok Cold Eddy" (Mitchell et al., 2005) may create an important pathway for southward flow from the western Japan Basin. The thick, warm subsurface layer in the Ulleung Warm Eddy can be considered a Subtropical Mode Water (e.g., Hanawa and Talley, 2001). The Ulleung Eddy is one of the three "Intrathermocline Eddies" (ITEs) described by Gordon et al. (2002), each characterized by a thick, warm subsurface water layer. The three ITEs are located in the major meanders of the inflowing Tsushima Strait water: the Ulleung Warm Eddy in the East Korean Warm Current where it separates from the coast $\left(130-131^{\circ} \mathrm{E}\right)$, and the oth- er two in the large meanders of the Tsushima Warm Current $\left(134^{\circ} \mathrm{E}\right.$ and $\left.137^{\circ} \mathrm{E}\right)$.

In the subpolar Japan Basin, very deep anticyclonic eddies occur on all five sections (locations in Figure 2; example cross section in Figure 5). Isotherm and isopycnal deflection extend to at least $2000 \mathrm{~m}$ in each eddy, and to the bottom in some. The deep penetration of high oxygen, high chlorofluorocarbons, and low nutrients in each of these eddies suggests a role in ventilating intermediate depths of the Japan/East Sea (e.g., Min and Warner, 2005). Salinity in the two northeastern eddies $\left(42^{\circ} \mathrm{N}\right.$ and $\left.44^{\circ} \mathrm{N}\right)$ was high, so we surmise that they were the source of the salinity maximum of the Upper Japan Sea Proper Water (see next section). Our winter observations of the large anticyclonic eddy near $131^{\circ} \mathrm{E}$ showed deep convection around the edges of the eddy (Talley et al., 2003). The newly convected water was then wrapped in streamers around the anticyclonic eddy. By summer, these appeared as deep penetration of upper-ocean properties within the eddy's core.

\section{WATER MASSES}

The shallow straits and isolation of the Japan/East Sea below the sill depths, combined with high-latitude convection and sea-ice processes that form deep and bottom water, produce the special character of Japan/East Sea water-mass structures. Water masses in the Japan/East Sea have been categorized based on temperature, salinity, and oxygen features. Highly accurate data are required to distinguish water masses by salinity because variations are so small. Oxygen, chlorofluorocarbon, carbon, and nutrient variations are much larger. Oxygen has been espe- 


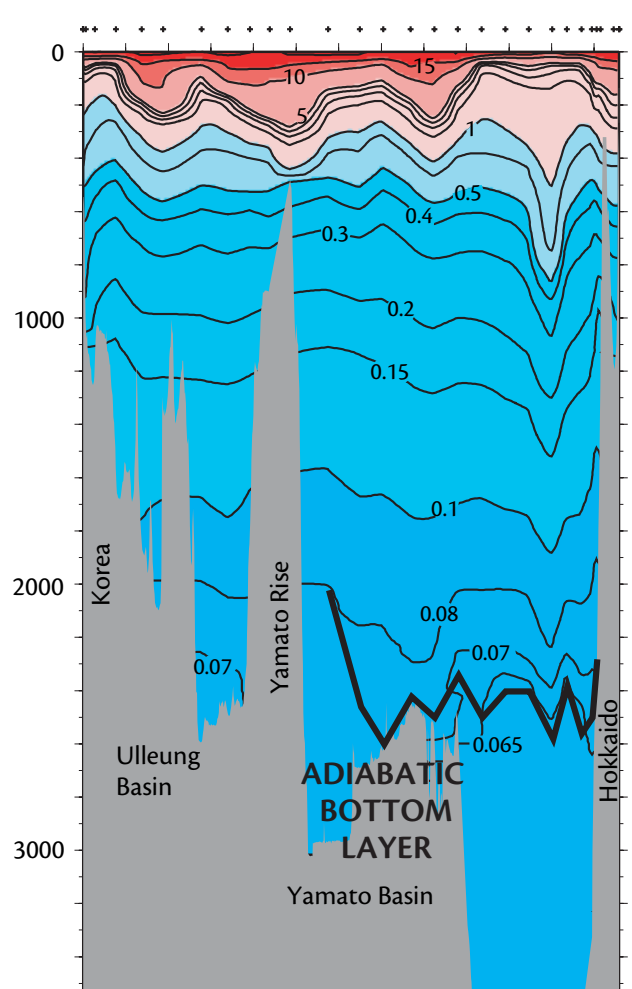

(a) Potential Temperature $\left({ }^{\circ} \mathrm{C}\right)$
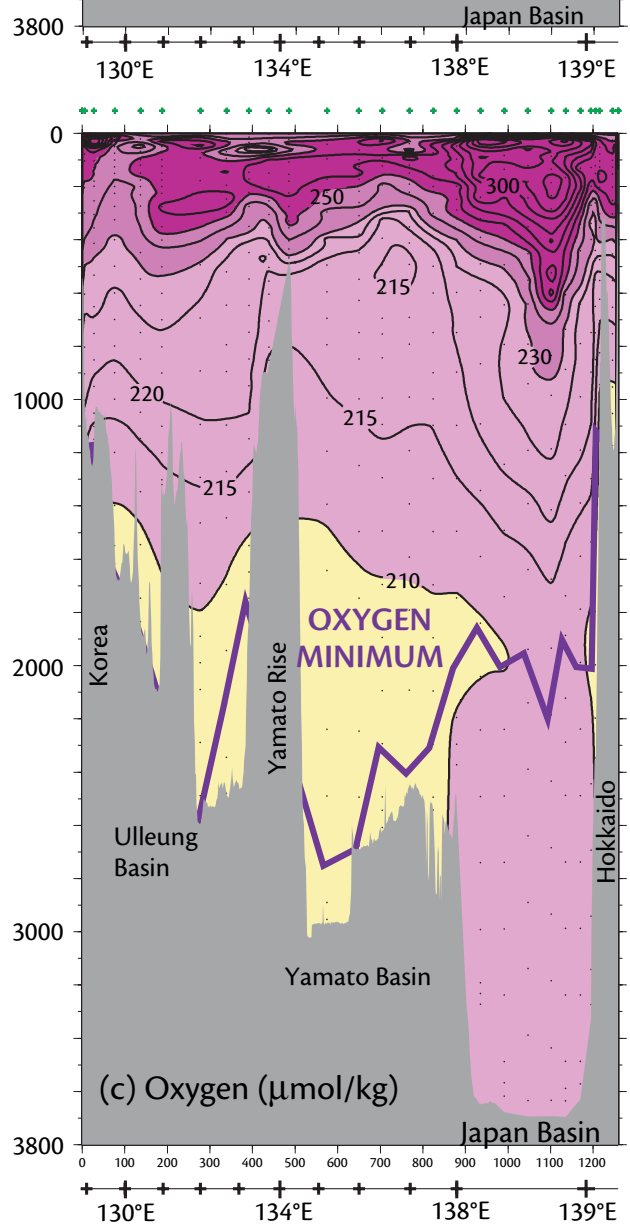

TSUSHIMA WARM WATER

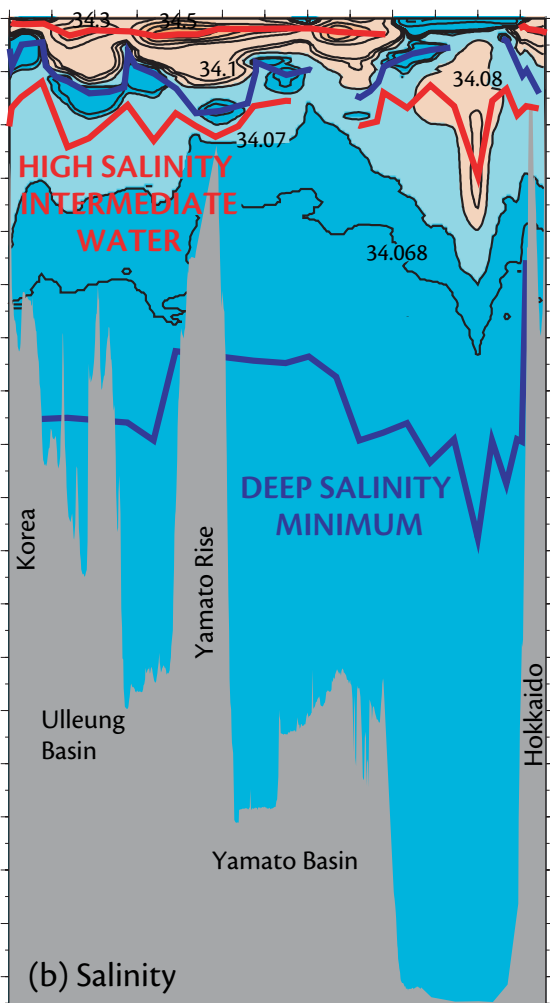

ESIW
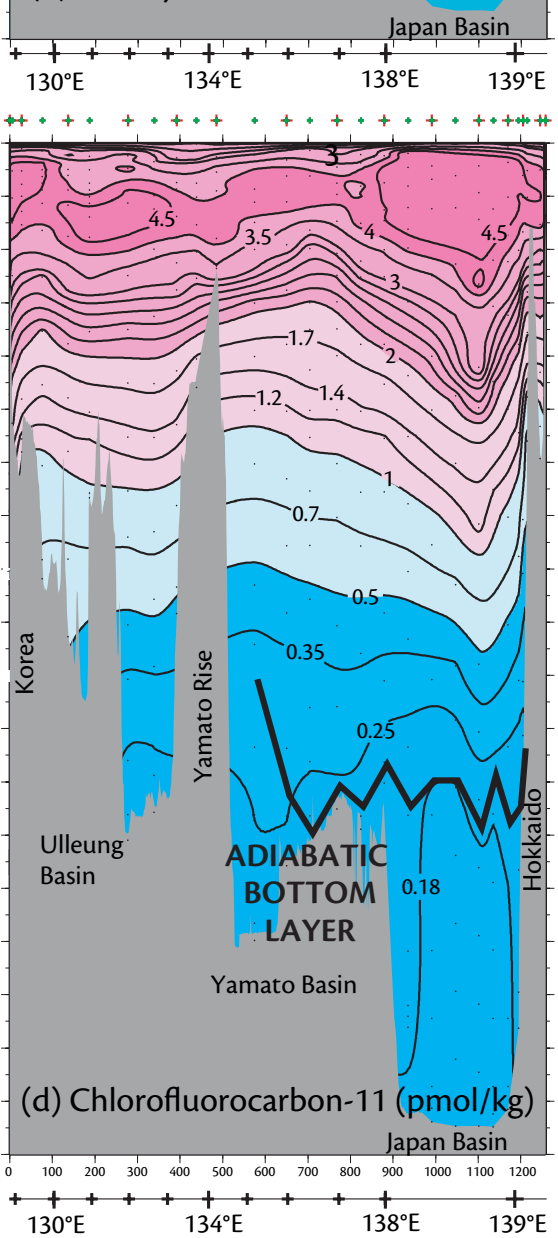

Figure 5. A cross section through the Japan/East Sea that crosses all three basins-the Ulleung (at $38^{\circ} \mathrm{N}$ ), Yamato (straight up the middle), and Japan Basins (eastern part at $138^{\circ} \mathrm{E}$ and then into the Hokkaido coast at $42^{\circ} \mathrm{N}$ ). One of the large eddies indicated in Figure 2 occurs near the right end of the section, between $138^{\circ}$ and $139^{\circ} \mathrm{E}$; contours of all properties dip way down in the eddy. There is an isolated core of high salinity within the eddy, which is the source of the High-Salinity Intermediate Water. (a) Potential temperature $\left({ }^{\circ} \mathrm{C}\right)$ shows how thin the warm surface layer is, with $1^{\circ} \mathrm{C}$ occurring at 200- to $400-\mathrm{m}$ depth. The top of the adiabatic bottom layer is indicated (black). (b) Salinity shows also how most variation is within the top $500 \mathrm{~m}$. The Tsushima Warm Water (heavy red) is apparent in the top $50 \mathrm{~m}$ as a salinity maximum. The salinity minimum of the East Sea Intermediate Water underlies this (blue, marked ESIW), beneath which is found the High-Salinity Intermediate Water (red). The Deep Salinity Minimum (blue at about $1500 \mathrm{dbar}$ ) is not apparent in contours on this vertical section because of the limitations of absolute accuracy of salinity data, but it is apparent in individual profiles (Figure 7). (c) Oxygen ( $\mu \mathrm{mol} \mathrm{kg}{ }^{-1}$ ) is high in the surface layer, with a subsurface maximum due mainly to lower temperature with high oxygen saturation. The oxygen minimum is apparent at about $2000 \mathrm{~m}$ (purple line), although its depth varies considerably. Within the Ulleung and Yamato Basins, it is nearly on the bottom. In the Japan Basin, the oxygen minimum is well above the bottom. (d) Chlorofluorocarbon-11 (pmol kg-1) (CFC-11) is similar to oxygen in the upper ocean, but much smoother in the deep ocean. The values of CFC-11 found in the deep Japan/East Sea vastly exceed the essentially zero values below $1000 \mathrm{~m}$ in the adjacent North Pacific, thus illustrating the active ventilation of the Japan/East Sea. The adiabatic bottom layer from (a) is also shown since it coincides with an interesting domed CFC-11 feature in the deep Japan Basin. 
cially useful for tracking decadal change in the deep water column. The summer 1999 survey, with highly accurate temperature and salinity data, a full complement of geochemistry, and nearly basinwide synoptic coverage, allows identification and mapping of the water masses. Deep and bottom water formation were clearly observed during the winter 2000 and 2001 surveys.

Because time dependence throughout the water column is large, water-mass definitions based on specific property ranges are not particularly useful. Following the practice for the North Atlan- tic Ocean, which also has large temporal changes, we define the water masses based on relative structures (extrema, gradients, location relative to strong currents) and formation processes (subduction, open-ocean convection, brine rejection). A further complication in formally defining water masses is the difference in Japanese and Korean nomenclature; we use a mix (Table 2) because neither set is comprehensive. We add one new water mass-Subtropical Mode Water (e.g., Hanawa and Talley, 2001).

The subtropical upper water column south (east) of the Subpolar Front in- cludes a shallow salinity maximum (Tsushima Warm Water), a shallow salinity minimum (East Sea Intermediate Water), and Subtropical Mode Water (Figure 5). All are part of the thermocline/pycnocline that is affected by subtropical subduction. These subtropical features, including the thermocline, are very shallow compared with an open ocean basin. This is likely due to the shallowness of the straits and the small basin size that precludes production of large amounts of thermocline water.

The subpolar gyre is ventilated in very thick mixed layers in winter: up

Table 2. Water Masses and Structures, Identifying Characteristics, and Source

\begin{tabular}{|c|c|c|}
\hline Water Mass & Distinguishing Characteristic & Source \\
\hline Tsushima Warm Water & Vertical salinity maximum in upper $150 \mathrm{~m}$ & $\begin{array}{l}\text { Tsushima Strait inflow, local evaporation } \\
\text { and subduction }\end{array}$ \\
\hline East Sea Intermediate Water & Vertical salinity minimum in upper ocean & $\begin{array}{l}\text { Subduction of fresh subpolar water southward } \\
\text { across the Subpolar Front }\end{array}$ \\
\hline Upper Japan Sea Proper Water & & Open ocean convection in the subpolar gyre \\
\hline $\begin{array}{l}\text { High-Salinity Intermediate Water } \\
\text { (Upper Japan Sea Proper Water) }\end{array}$ & $\begin{array}{l}\text { Vertical salinity maximum between } \\
200-500 \mathrm{~m}\end{array}$ & $\begin{array}{l}\text { Convective cooling of Tsushima Warm Water } \\
\text { in the northeast subpolar gyre }\end{array}$ \\
\hline Central Water & $\begin{array}{l}\text { Water between the salinity maximum and } \\
\text { deep salinity minimum }\end{array}$ & Deep convection \\
\hline Lower Japan Sea Proper Water & & $\begin{array}{l}\text { Most likely sea-ice formation and brine } \\
\text { rejection }\end{array}$ \\
\hline $\begin{array}{l}\text { Deep Salinity Minimum } \\
\text { (Lower Japan Sea Proper Water) }\end{array}$ & $\begin{array}{l}\text { Weak vertical salinity minimum at about } \\
1500-\mathrm{m} \text { depth }\end{array}$ & $\begin{array}{l}\text { Convection or brine rejection in the western } \\
\text { subpolar gyre }\end{array}$ \\
\hline $\begin{array}{l}\text { Oxygen Minimum } \\
\text { (Lower Japan Sea Proper Water) }\end{array}$ & $\begin{array}{l}\text { Vertical oxygen minimum at about } \\
2000 \text {-m depth }\end{array}$ & $\begin{array}{l}\text { Biological consumption in water column } \\
\text { and in sediments }\end{array}$ \\
\hline $\begin{array}{l}\text { Deep Water } \\
\text { (Lower Japan Sea Proper Water) }\end{array}$ & $\begin{array}{l}\text { Water between the salinity minimum and } \\
\text { the bottom layer }\end{array}$ & $\begin{array}{l}\text { Most likely sea-ice formation and brine } \\
\text { rejection }\end{array}$ \\
\hline $\begin{array}{l}\text { Bottom Water } \\
\text { (Lower Japan Sea Proper Water) }\end{array}$ & $\begin{array}{l}\text { High oxygen bottom layer (following } \\
\text { winter 2001) }\end{array}$ & Sea-ice formation and brine rejection \\
\hline $\begin{array}{l}\text { Bottom Adiabatic Layer } \\
\text { (Lower Japan Sea Proper Water) }\end{array}$ & Vertically homogeneous bottom layer & Turbulent mixing of bottom waters \\
\hline
\end{tabular}


to 400 - $m$ thick in a broad region of the northeastern Japan Sea, and to at least $1200 \mathrm{~m}$ in a limited region south of Peter the Great Bay. These mixed layers form the Upper Japan Sea Proper Water, which includes a salinity maximum ventilated in the eastern Japan Basin's winter mixed layers (High-Salinity Intermediate Water). Brine rejection due to ice formation on the northern continental shelves, especially in Peter the Great Bay, provides the deep and bottom waters, known collectively as Lower Japan Sea Proper Water. This layer, which is up to 2500-m thick, includes a deep salinity minimum, a deep oxygen minimum, thick adiabatic bottom layers, and occasionally a high-oxygen bottom boundary layer (when there has been recent production of brine-rejected water that reaches the bottom).

\section{Subtropical Water Masses}

Tsushima Warm Water is the salinity maximum close to the sea surface, with its core at about 50-m depth in the potential density range 24.0 to $26.5 \mathrm{~kg} \mathrm{~m}^{-3}$. It is found throughout the Japan/East Sea south and east of the Subpolar Front (Figures 4, 5, 6), but is concentrated in the Tsushima Warm Current (Offshore and Nearshore Branches). The high salinity is usually ascribed to inflow through Tsushima Strait. However, in summer 1999, the saltiest Tsushima Warm Water was not in Tsushima Strait, but downstream (Figure 6b). This downstream location of salty water can be due either to variable salinity in the Tsushima Strait inflow or evaporation within the Japan/East Sea. In favor of the former, oxygen is low in both the inflow and in the highest-salinity parts of the Tsu- shima Warm Water. The advective time scale from Tsushima Strait to the highest salinity is also short, only one month and, given the observed current speed of about $20 \mathrm{~cm} \mathrm{sec}^{-1}$, could result in a fast response to changing inflow properties.

Tsushima Warm Water salinity decreases dramatically north of $40^{\circ} \mathrm{N}$ where it is first affected by fresher water from the Subpolar Front ( $<34.3$ in Figure 6b). Tsushima Warm Water density also increases after this dilution. This increase in density is due to erosion of the layer from above, which might also account for some of the apparent freshening. The same salinity and density changes occur at the western boundary, where high-salinity Tsushima Warm Water in the East Korean Cold Current meets the fresher subpolar waters in the North Korean Cold Current. The Dok Cold Eddy (blue ellipse at $38^{\circ} \mathrm{N}, 132^{\circ} \mathrm{E}$ in Figure 2) (Chang et al., 2004; Mitchell et al., 2005) includes this fresher, colder, denser, salinity-maximum water, suggesting a North Korean Cold Current origin of this eddy.

East Sea Intermediate Water is the salinity-minimum layer in the subtropical Japan/East Sea at about 200-m depth, with a core potential density of 27.1 to $27.2 \mathrm{~kg} \mathrm{~m}^{-3}$ (Figures 5, 6) (Kim and Chung, 1984). The salinity minimum originates at the fronts between subtropical and subpolar waters (Miyazaki, 1953), including the Subpolar Front and the front between the North Korean Cold Current and the East Korean Warm Current at the western boundary. The winter surface water at these fronts is subducted southwards into the subtropical gyre as the densest thermocline water; because surface salinity is lower in the north, a subtropical salinity mini- mum is created-East Sea Intermediate Water (Yoshikawa et al., 1999). The underlying high salinity that defines the salinity minimum is Upper Japan Sea Proper Water, which is the dominant convective product from the subpolar gyre and which derives its high salinity from Tsushima Warm Water.

East Sea Intermediate Water is not found in the Nearshore Branch of the Tsushima Warm Current, likely because of the strong salinity maximum of the Tsushima Warm Water. Chlorofluorocarbon observations and multivariate analysis indicate that waters in the East Sea Intermediate Water density range in the Tsushima Warm Current do contain a significant fraction of East Sea Intermediate Water from the Subpolar Front (Min and Warner, 2005), but the salinity minimum is obliterated by the strength of the salinity maximum and diapycnal mixing.

There are two regimes of East Sea Intermediate Water: (1) a northern type that is relatively fresher, warmer, lighter, and more oxygenated, found between about $38^{\circ} 30^{\prime} \mathrm{N}$ and the Subpolar Front, extending eastward and then northward along Hokkaido; and (2) a southern type that is saltier, colder, denser, and lower in oxygen, found in the Ulleung Basin and Offshore Branch of the Tsushima Warm Current. The latter, saltier type of East Sea Intermediate Water could be due to higher-density subduction at the North Korean Cold Current than at the Subpolar Front, but this does not account for its lower oxygen content. Alternatively, the fresher, northern East Sea Intermediate Water might be advected southward into the Ulleung Basin, along about $131^{\circ} \mathrm{E}$ (Figures 2 and 3 ), with erosion of 

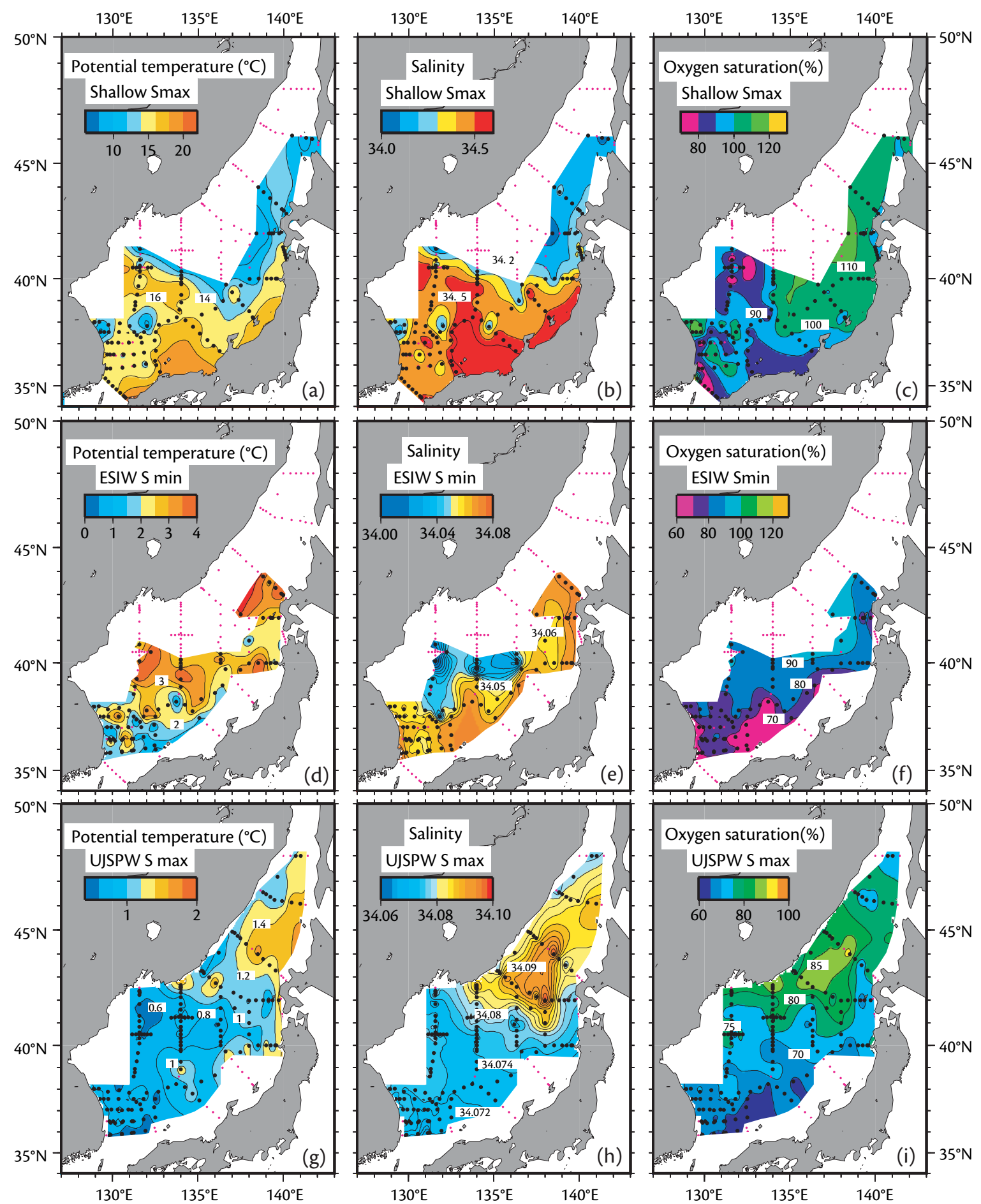

Figure 6. Potential temperature $\left({ }^{\circ} \mathrm{C}\right)$, salinity, oxygen saturation (\%) for: $(\mathrm{a}, \mathrm{b}, \mathrm{c})$ Tsushima Warm Water (shallow salinity maximum): this layer is very shallow, around 50-m depth (see Figure 5). Highest salinity, highest temperature, but lowest oxygen saturation is in the Tsushima Warm Current. This current is joined by cooler, fresher, more oxygenated water from the Subpolar Front as the current proceeds north towards Hokkaido. The salinity maximum is not present north of the Subpolar Front. (d, e, f) East Sea Intermediate Water (upper ocean salinity minimum): lowest salinity and highest temperature and oxygen are in the Subpolar Front region, while a second type with slightly higher salinity, cooler temperature, and lower oxygen is found in the Ulleung Basin and Tsushima Warm Current region. The salinity minimum does not occur north of the Subpolar Front or in much of the Tsushima Warm Current. (g, h, i) Upper Japan Sea Proper Water (salinity maximum): highest salinity occurs in the eastern Japan Basin, which is the source of the salinity maximum water (High-Salinity Intermediate Water). This region also has highest oxygen saturation. 
its salinity minimum from above by the Tsushima Warm Water. The resulting modified salinity minimum would be deeper and with lower oxygen content, which is consistent with the small variations in properties along isopycnals that intersect the East Sea Intermediate Water (Talley et al., 2004). The saltier Ulleung Basin East Sea Intermediate Water is picked up by the Offshore Branch of the Tsushima Warm Current and carried back to the north.

Subtropical Mode Water (e.g., Hanawa and Talley, 2001) has not been described specifically for the Japan/East Sea, but there are a number of publications about thick near-surface layers in the East Korean Warm Current and Offshore Branch of the Tsushima Warm Current. Specifically, the ITEs described by Gordon et al. (2002) are identified by thick, near-surface layers. These thick layers can be considered Subtropical Mode Water. Identification as such could assist interpretation of the formation of these layers. As mentioned earlier, the thick layer in the Ulleung Basin Warm Eddy, which is an ITE, is a continuation of a narrow band of thick, near-surface layers along the East Korean Warm Current from its inception north of Tsushima Strait, lending support to classification as a mode water.

\section{Japan Sea Proper Water} (Subpolar Water Masses)

All of the subtropical water from about $300 \mathrm{~m}$ to the bottom and all of the subpolar water in the Japan/East Sea is ventilated north of the Subpolar Front. All of this subpolar-ventilated water can be referred to as Japan Sea Proper Water, once thought to be a nearly homoge- neous water mass (Uda, 1934); however, accurate, modern measurements have shown the Japan Sea Proper Water to be several water masses with separate sources (e.g., Sudo, 1986; Kim et al., 1996, 2004). Because the Japan/East Sea is small and not in steady state, interpretation of property distributions, including those used to label the water masses, is complicated.

There are two subpolar deep-water ventilation sources: open-ocean winter mixed-layer convection and brine rejection during ice formation (Vasiliev and Makashin, 1992). Turbulent mixing within the water column also spreads the influence of directly ventilated products. Open-ocean convection ventilates the Japan/East Sea to intermediate depths. Surface mixed layers in the northern Japan/East Sea are remarkably thick, very similar to those of the northern North Atlantic and Antarctic Circumpolar Current. Normal, widespread winter convection in the subpolar region creates 300-400-m mixed layers (Senjyu and Sudo, 1993, 1994; Talley et al., 2003), which can be considered to be Subpolar Mode Water (Sudo, 1986). Deepest open-ocean convection likely reaches to approximately 1000-1200-m deep in the western Japan Basin (Talley et al., 2003). Brine rejection during ice formation ventilates the remainder of the water column. Ice formation occurs in Tatar Strait, along the Primorye coast, and in Peter the Great Bay. The highest density shelf waters produced by brine rejection are in Peter the Great Bay at the end of the cyclonic subpolar circulation.

Japan Sea Proper Water is divided into Upper Japan Sea Proper Water (Upper JSPW) and deep water (Sudo, 1986); we refer to the latter as Lower Japan Sea Proper Water (Lower JSPW). Senjyu and Sudo (1993) define the boundary between the two based on the top of an oxycline. Waters above the boundary have higher oxygen, even including an oxygen maximum (Figure $7 \mathrm{~b}$ ). Winterconvection observations (e.g., Talley et al., 2003) support this division: waters formed through open-ocean convection constitute the high-oxygen upper layer, and waters formed either much more intermittently through convection or through brine rejection constitute the lower layer. The Lower JSPW includes a Deep Salinity Minimum, a deep oxygen minimum, remarkably thick adiabatic bottom layers, and occasionally highoxygen products of brine rejection.

\section{Upper Japan Sea Proper Water} Upper Japan Sea Proper Water includes the thick subpolar winter surface mixed layer. A salinity maximum layer called the High-Salinity Intermediate Water (Watanabe et al., 2001) is formed as part of this overall subpolar winter-outcropping layer. The salinity maximum was located at about 400-m depth and had a potential density $\left(\sigma_{\theta}\right)$ of $27.31-$ $27.32 \mathrm{~kg} \mathrm{~m}^{-3}\left(0.8^{\circ}\right.$ to $\left.1^{\circ} \mathrm{C}\right)$ at all stations outside the Tsushima Warm Current in summer 1999.

In vertical cross section (Figure 5), the separation between the High-Salinity Intermediate Water (HSIW) and the shallower Tsushima Warm Water salinity maxima is clear. In the subtropics, the East Sea Intermediate Water salinity minimum lies between them. In the subpolar region, only the deeper salinity maximum is found. The formation site of the HSIW is the eastern Japan Basin 

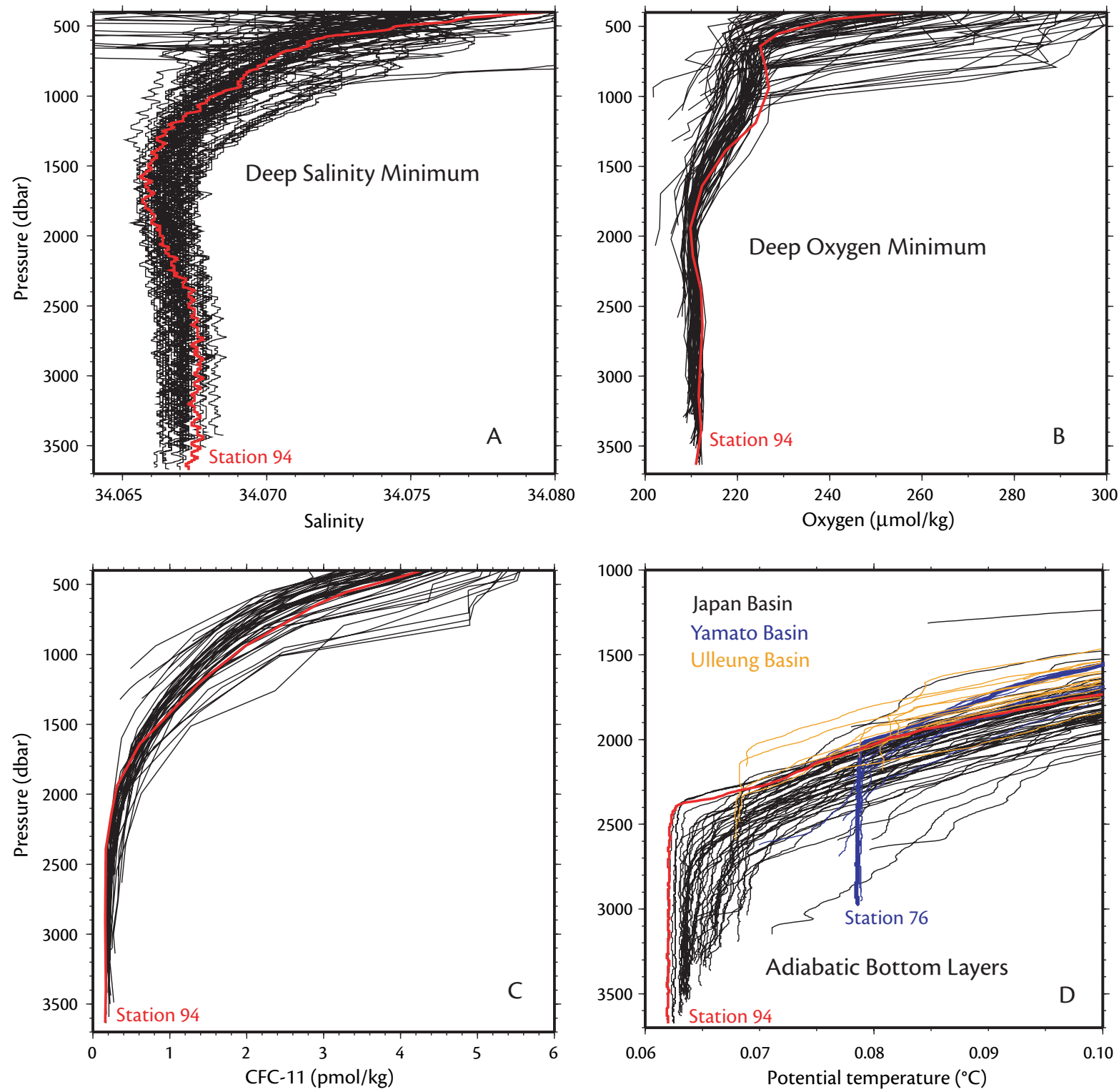

Figure 7. All Japan Basin CTD and bottle data profiles, plotted below the thermocline. A Japan Basin station $\left(41^{\circ} 30^{\prime} \mathrm{N}, 138^{\circ} \mathrm{E}\right)$ is highlighted in red. (a) The Deep Salinity Minimum is a feature of many of the deep CTD salinity profiles. The overall spread of salinity values is due to the absolute accuracy of the salinity calibration, which is 0.002 psu. However, within each profile, precision is higher, and so the salinity minimum can be discerned. (b) The deep oxygen minimum occurs around $2000 \mathrm{dbar}$, in this figure based on the bottle data. The profiles in general are complex, with a maximum at around $100 \mathrm{dbar}$ and another minimum around 500 to $700 \mathrm{dbar}$. Note that oxygen values in all of these profiles are high compared with values in the open Pacific shown in Figure 1, illustrating how well ventilated the Japan/East Sea is to the bottom. (c) The chlorofluorocarbon-11 profiles decay nearly exponentially with depth, in stark contrast to the oxygen profiles. Since CFCs are inert, they much more closely reflect the age of the water parcel. Therefore, the complexities of the oxygen profiles are due to variations in biological consumption. (d) Deep potential temperature profiles illustrate the occurrence of adiabatic bottom layers, which have uniform potential temperature. Note though that not all deep profiles exhibit adiabatic bottom layers. All Yamato Basin stations are in blue; all Ulleung Basin stations are in yellow. One Yamato Basin station $\left(38^{\circ} 21^{\prime} \mathrm{N}, 135^{\circ} 13^{\prime} \mathrm{E}\right)$, with a strong adiabatic bottom layer, is highlighted in heavier blue. 


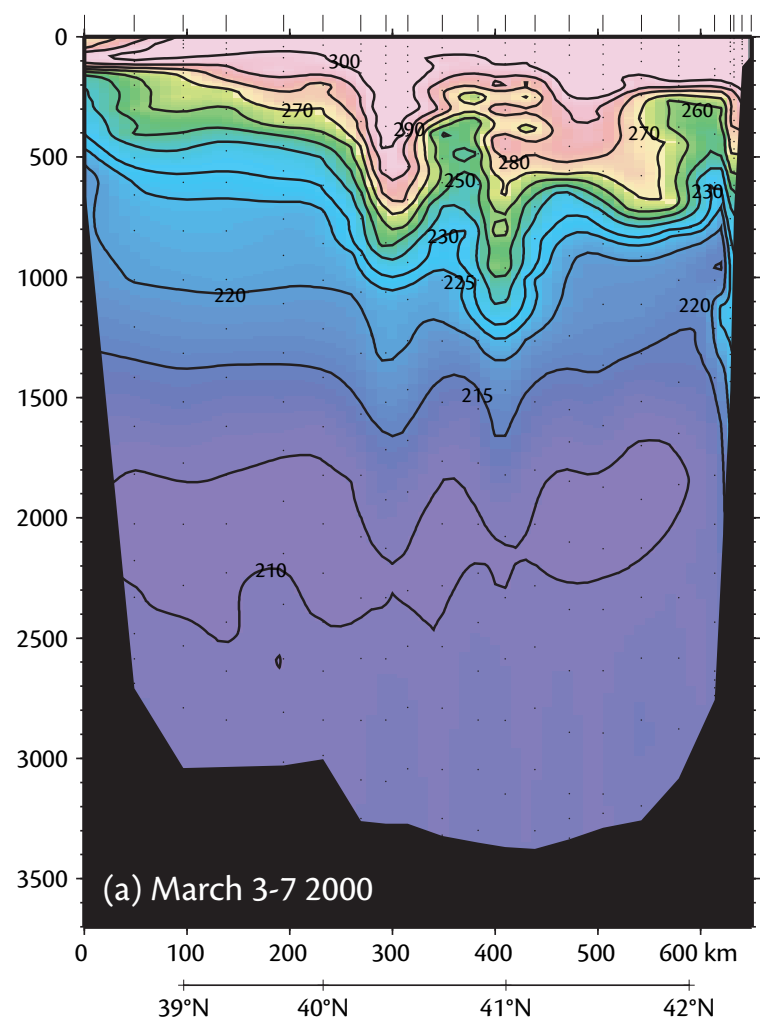

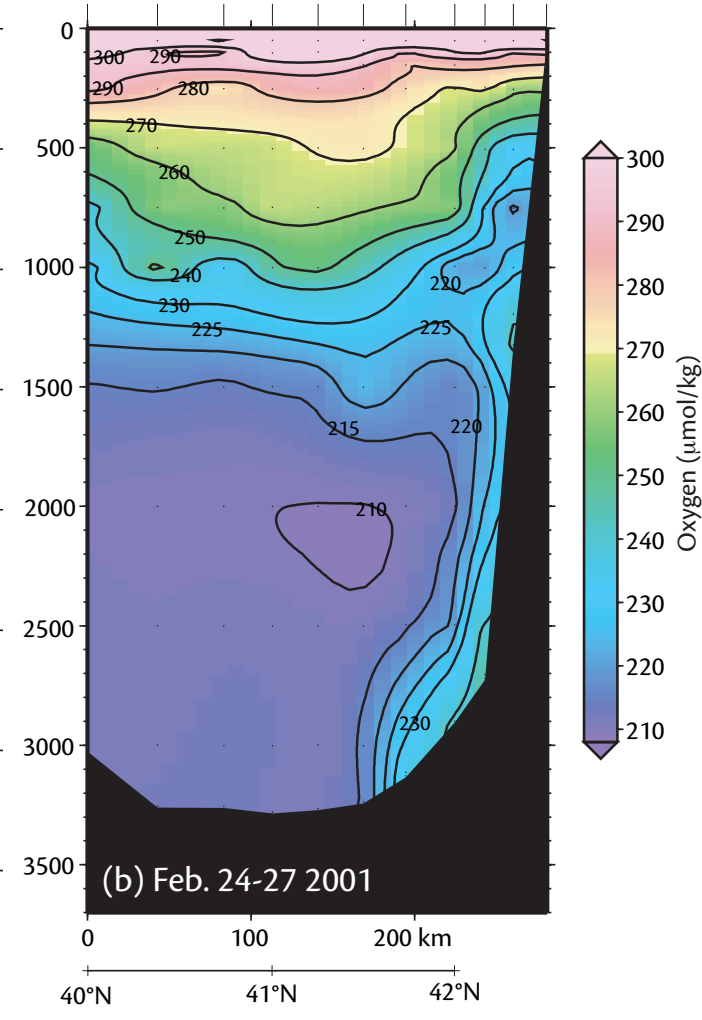

Figure 8. Oxygen $\left(\mu \mathrm{mol} \mathrm{kg}{ }^{-1}\right)$ in winter along $131^{\circ} 30^{\prime} \mathrm{E}$.

(a) March 3-7, 2000.

(b) February 24-27, 2001 (from Talley et al., 2003). In the first winter, the oxygen-minimum layer is well developed at about 2000 m, with a small rise towards the bottom, also seen in the profiles in Figure 7b. There is a narrow band of high oxygen penetrating down at the northern boundary, which was most likely due to brine-rejected surface waters from the continental shelf. In the second winter, there was much more of this brine-rejected shelf water. Also, high upper-ocean oxygen in the main part of the section was about 500-m deeper than in the first winter, reflecting a much higher open-ocean convection rate. $\left(43-45^{\circ} \mathrm{N}\right)$, offshore of the northern end of the Tsushima Warm Current, based on the location of highest salinity and highest oxygen (> 90 percent) in the HSIW and on an intersecting isopycnal (Figure $6 \mathrm{~g}$, h, i and $27.32 \sigma_{\theta}$ in Talley et al., 2004). Indeed, a deep mixed layer in this region with the same high salinity as the HSIW was found in 2000, and is considered direct evidence of ventilation. Yoshikawa et al. (1999) identified this ventilation region, also using oxygen data, whereas Watanabe et al. (2001) suggested a northwestern Japan Basin source for the salinity maximum.

We conclude that the HSIW arises from inflowing high salinity from the Tsushima Warm Current off the coast of Hokkaido. Winter mixed-layer convec- tion cools the saline water, shifting it to higher density and depth, with the deepest penetration in the eastern central Japan Basin. Fresher water from the rest of the subpolar region or precipitation then caps it over in the summer (assuming that winter 2000 was similar to winter 1999).

Upper JSPW includes much more than just the HSIW, which is ventilated in the eastern Japan Basin. Deeper ventilation of Upper JSPW also occurs in the western Japan Basin. These conclusions are based on measurements of high-oxygen and chlorofluorocarbon content within the Upper JSPW (Talley et al., 2004) and, more directly, on observations of convection at $131^{\circ} 30^{\prime} \mathrm{E}$ in winter 2000 and 2001 (Figure 8 from
Talley et al., 2003). Salinity at this western source was lower than at the northeastern source. The lower temperature of this western Upper JSPW extended eastward at $40^{\circ} \mathrm{N}$ along the Subpolar Front (Figure 6g).

Upper JSPW spreads southward into the Ulleung Basin and Tsushima Warm Current regions via southward flow between the Ulleung Warm and Dok Cold Eddies. The Upper JSPW's salinity maximum is absent in the Tsushima Warm Current. Properties on isopycnals intersecting the Upper JSPW (27.30 $\sigma_{\theta}$ and $27.32 \sigma_{\theta}$ in Talley et al., 2004) show lower oxygen ( $40 \mu \mathrm{mol} \mathrm{kg}{ }^{-1}$ lower), lower chlorofluorocarbons, and lower salinity than in the Japan Basin formation region. These data indicate that the Hon- 
shu coastal region is a long way from the Upper JSPW formation region, in fact, directly upstream.

\section{Lower Japan Sea Proper Water}

Below the Upper JSPW, the Japan/East Sea is more intermittently ventilated. Oxygen and chlorofluorocarbons drop to much lower values (Figures 5, 7, 8), although even the lowest values are much higher than in the adjacent Pacific. Although the chlorofluorocarbon and noble gas vertical structures are essentially exponential, at least prior to winter 2001 (Min and Warner, 2005; Postlethwaite et al., 2005), the vertical oxygen structure is complicated, with minima at about $600 \mathrm{~m}$ and $2000 \mathrm{~m}$, a weak maximum at $1000 \mathrm{~m}$, and higher bottom values. The oxygen structure is thus not simply a balance of ventilation and uniform biological consumption; the strong minimum at $2000 \mathrm{~m}$ is mapped and discussed here. Deep salinity structure includes a very weak salinity minimum around $1500 \mathrm{~m}$ (Figure 7a) known as Deep East Sea Intermediate Water or the Deep Salinity Minimum (Kim et al., 1996; Kim et al., 2004). The bottom waters are nearly adiabatic in places, but there is important lateral structure associated with the deep topography.

The Deep Salinity Minimum (Figures $7 \mathrm{a}$ and $9 \mathrm{a}, \mathrm{b}, \mathrm{c})$ is pervasive at water depths of $1500 \mathrm{~m}$ and greater in the Japan/East Sea. The salinity difference between the minimum and the bottom waters is on the order of 0.001 psu. This difference is detectable in our high-quality conductivity-temperature-depth (CTD) data with precision of 0.0005 or better within a given profile, and in Kim et al.'s (2005) individual CTD profiles. It is not detectable with bottle samples using an autosalinometer, where the highest accuracy is 0.002 , in accord with World Ocean Circulation Experiment (WOCE) Hydrographic Programme standards (Saunders et al., 1994). It is also not possible to map the Deep Salinity Minimum salinity from one CTD profile to another, because such mapping is based on the accuracy of the bottle samples used to calibrate the CTD salinity.

The Deep Salinity Minimum core potential density in summer 1999 was $27.346 \sigma_{\theta}$. Water of this density or to this depth was not formed in winter 2000 or 2001 through convection. The maximum depth of normal convection prior to our 1999-2001 surveys might be indicated by the vertical oxygen maximum at about $1000 \mathrm{~m}$ (Figure 7b), which roughly coincides with the maximum convection depth in winters 2000 and 2001. Thus, we conclude that Deep Salinity Minimum is not a product of deep convection, at least from recent years.

A deep oxygen minimum is found in much of the Japan/East Sea at around $2000 \mathrm{~m}$ or at the bottom (Figures 5, 8, 9). It has no counterpart in chlorofluorocarbons (Figure 7c) (Min and Warner, 2005). The oxygen minimum results from combined ventilation and biological processes. The lowest values of deep oxygen $\left(<200 \mu \mathrm{mol} \mathrm{kg} \mathrm{kg}^{-1}\right)$ are found in bottom samples in the Ulleung Basin (Figure 9d). The oxygen minimum is weakest and far above the bottom in the Japan Basin. Here the most extreme oxygen minima are very narrow $(<40-\mathrm{km}$ wide) features on the boundaries of the Japan Basin (e.g., at Hokkaido in Figure $5 c$ ) and on the northern edge of Yamato Rise (section at $134^{\circ} \mathrm{E}$ in Talley et al., 2004), suggesting narrow, deep boundary currents that advect low oxygen from the Ulleung and Yamato Basins and northeastern Japan Basin.

The lowest deep oxygen levels at the seafloor are accompanied by measurable deep nitrite, which is highly unusual and suggestive of sedimentary denitrification (e.g., Christensen et al., 1987). There is also a significant perturbation in a Redfield-ratio quantity derived from nitrate and phosphate but none in chlorofluorocarbons. These suggest that the deep oxygen minimum is influenced by sedimentary denitrification (Jahnke and Jackson, 1987).

Highest oxygen at the oxygen minimum occurs in the eastern central Japan Basin. Deep oxygen had been decreasing rapidly prior to 1999 (Kim et al., 1996), so the highest values observed in 1999 were considerably lower than observed in previous years. The central Japan $\mathrm{Ba}$ sin was most likely the farthest distance from the boundaries where denitrification was taking place, and so higher oxygen here does not imply younger age. Min and Warner (2005) note that the lowest deep chlorofluorocarbons occur in this region, despite the higher oxygen levels here.

Adiabatic bottom layers. A significant group of stations in the Japan and Yamato Basins have remarkably adiabatic bottom layers (Gamo et al., 1986; Kim et al., 2004), which are mapped here for the first time (Figures 7d and 9g, h, i). A potential temperature change of $0.001^{\circ} \mathrm{C}$ above the bottom potential temperature is used here to define the layers. The thickest adiabatic layers appear in the deepest parts of the basins (Japan and Yamato), farthest from the source of 

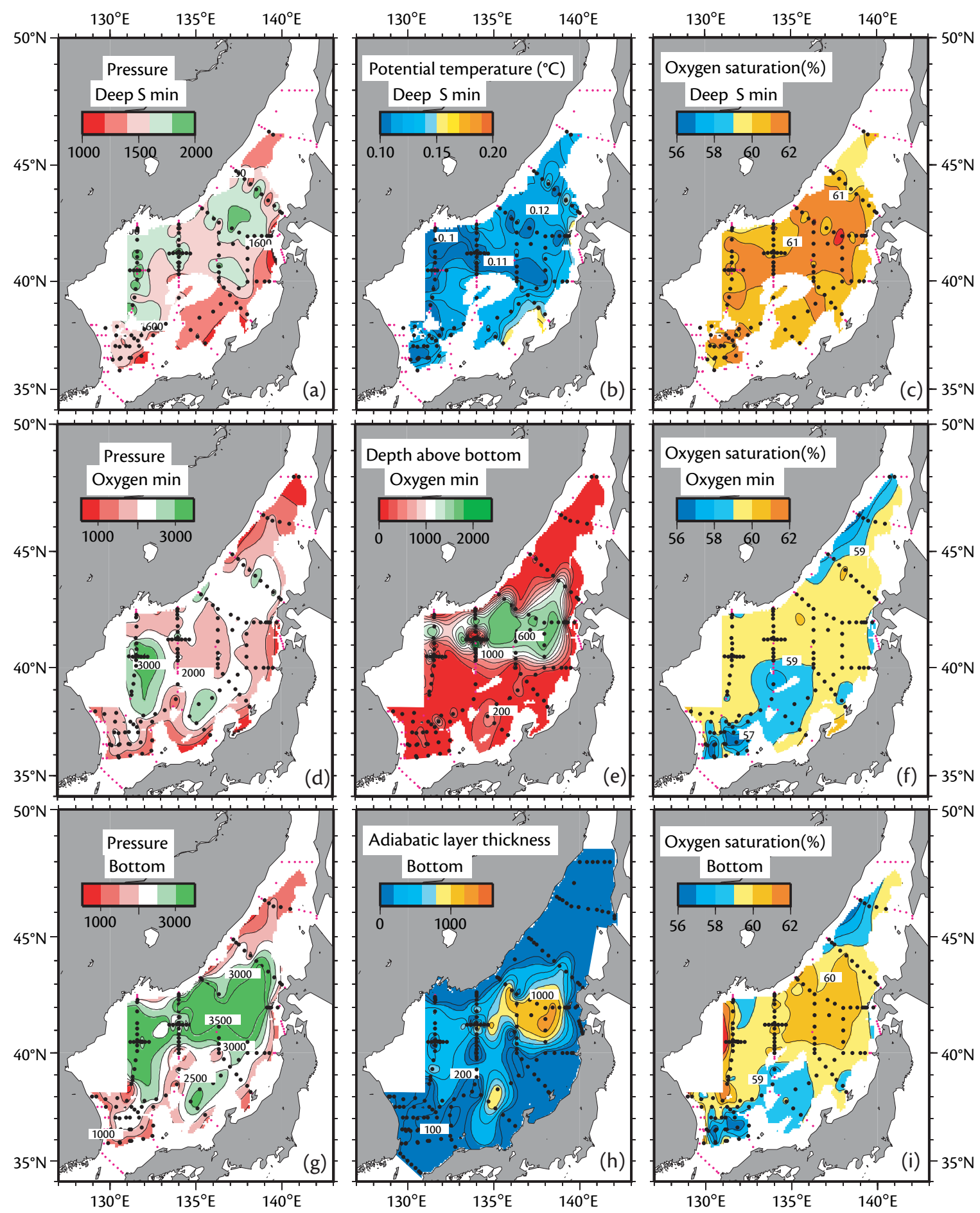

Figure 9. (a, b, c) Deep Salinity Minimum using CTDO (conductivity, temperature, depth, oxygen) data: Pressure (dbar), potential temperature $\left({ }^{\circ} \mathrm{C}\right)$, and oxygen saturation (\%). Depths shallower than $1500 \mathrm{~m}$ are masked in white and roughly match the edge of the water mass. Salinity is not shown because station-to-station variation is smaller than the absolute accuracy of salinity measurements. ( $d, e, f)$ Deep oxygen minimum: Pressure (dbar), depth above bottom of the oxygen minimum ( $\mathrm{m}$ ), and oxygen saturation (\%). In most of the sea, the oxygen minimum is very close to the bottom. The exception is in the Japan Basin where the oxygen minimum floats out at mid-depth. (g,h,i) Adiabatic bottom layers: Bottom pressure ( $\mathrm{dbar}$ ), thickness of the adiabatic bottom layer using a criterion of $\Delta_{\theta}=0.001^{\circ} \mathrm{C}$, and bottom oxygen saturation (\%). The very thick bottom layers are restricted to the eastern Japan Basin and the southern Yamato Basin. There is no apparent correlation between these layers and their oxygen values, indicating that the existence of thick adiabatic bottom layers is not associated with age. 
deep waters (Peter the Great Bay for the Japan Basin, and the passage between the Japan and Yamato Basins for the latter). The Japan Basin layers have temperatures around 0.062 to $0.064^{\circ} \mathrm{C}$, and a maximum thickness of $1280 \mathrm{~m}$ (red profile in Figure 7d). They are least developed at $131^{\circ} \mathrm{E}$, near the observed site of bottom-water production near Peter the Great Bay.

The southern Yamato Basin adiabatic layers are also extraordinarily thick (780-940 m), at a higher temperature of $0.079^{\circ} \mathrm{C}$ (blue profile in Figure $7 \mathrm{~d}$ ). The higher temperature reflects the sill depth between the Japan and Yamato Basins because the Japan Basin is the source of Yamato Basin bottom waters. (The sill depth also provides an explanation for the contradictory chlorofluorocarbon and oxygen evidence for the age of Yamato Basin bottom waters in Min and Warner [2005]. With oxygen increasing towards the bottom and chlorofluorocarbons decreasing towards the bottom, the Yamato Basin bottom water has higher chlorofluorocarbons and lower oxygen than the deeper Japan Basin bottom waters.)

Deep and bottom water ventilation. The mechanism for direct ventilation of Lower JSPW is most likely brine rejection along the northern boundary. Ventilation had apparently not occurred in great quantity in the years prior to summer 1999, based on the smooth temperature, salinity, and oxygen profiles. In the exceedingly cold winter of 2000-2001, brine-enriched waters were evident all the way down the continental slope in the same region, and were beginning to pool as bottom water in the Japan Basin (Figure 8b from Talley et al., 2003).
Based on subsequent observations, the bottom-water pool eventually filled a large region and began to spread eastward in a layer about 100-m thick, which was characterized by high oxygen and low potential temperature. Even in winter 1999-2000 there was a small blob of higher-oxygen, brine-enriched water at $1200 \mathrm{~m}$ (Figure 8a). Thus, we conclude that deep- and bottom-water formation in the Japan/East Sea had indeed not ceased, despite the overall decrease in oxygen content of the Lower Japan Sea Proper Water since the 1930s. This same conclusion was reached from the observation of measurable chlorofluorocarbons in the deep and bottom waters (Min and Warner, 2005).

\section{SUMMARY}

The Japan/East Sea is well ventilated to the bottom through processes of subduction, open-ocean convection, and brine rejection from sea-ice production. The Japan/East Sea has a relatively short overturning time scale, and thus its deep- and bottom-water properties are in flux, tied to changing surface conditions with a delay of only decades. Concerns about possible anoxia in the abyss within a century or two may be ill founded based on observations of new bottom-water production. On the other hand, because sea ice is the source of deep and bottom water in the Japan/ East Sea, changes in climate that greatly reduce or eliminate sea ice in the Japan/ East Sea could have a profound impact on its abyssal waters.

The impact of the Japan/East Sea processes on North Pacific properties is indirect but important. The Tsushima Warm Current draws subtropical North
Pacific water northward where it is transformed by air-sea fluxes; transformed surface water exits at Tsugaru Strait, several hundreds of kilometers north of the Kuroshio. Relatively saline waters are also advected farther northward to the Soya Strait to enter the Okhotsk Sea. In both locations, the Japan/East Sea waters are more saline than the ambient waters and cold enough to affect the properties of North Pacific Intermediate Water, which is the densest water formed in the open North Pacific. The freshening and cooling processes within the Japan/East Sea and overall budgets that affect the outflow properties through these shallow straits thus impact overturning of the North Pacific. 시

\section{REFERENCES}

Aota, M., and T. Yamada. 1990. Physical oceanography of Soya Strait. Pp. 428-437 in Coastal Oceanography of Japanese Islands, Suppl. vol, Committee on Coastal Oceanography in the Oceanographic Society of Japan, eds. Tokai University Press, Kanagawa, Japan (in Japanese).

Chang, K.-I., W.J. Teague, S.J. Lyu, H.T. Perkins, D.-K. Lee, D.R. Watts, Y.-B. Kim, D.A. Mitchell, C.M. Lee, and K. Kim. 2004. Circulation and currents in the southwestern East/Japan Sea: Overview and review. Progress in Oceanography 61:105-156.

Christensen, J.P., J.W. Murray, A.H. Devol, and L.A. Codispoti. 1987. Denitrification in continental shelf sediments has major impact on the oceanic nitrogen budget. Global Biogeochemical Cycles 1:97-116.

Chu, P.C., J. Lan , and C. Fan. 2001. Japan Sea thermohaline structure and circulation. Part II: A variational P-vector method. Journal of Physical Oceanography 31:2,886-2,902.

Gamo, T., Y. Nozaki, H. Sakai, T. Nakai, and H. Tsubota. 1986. Spatial and temporal variations of water characteristics in the Japan Sea bottom layer. Journal of Marine Research 44:781-793.

Gordon, A.L., C.F. Giulivi, C.M. Lee, H.H. Furey, A. Bower, and L. Talley. 2002. JES intrathermocline eddies. Journal of Physical Oceanography 32:1,960-1,974.

Hanawa, K., and L.D. Talley. 2001. Mode waters, ocean circulation and climate. Pp. 373-386 in 
International Geophysics Series, G. Siedler and J. Church, eds. Academic Press, New York.

Isobe, A., M. Ando, T. Watanabe, T. Senjyu, S. Sugihara and A. Manda. 2002. Freshwater and temperature transports through the Tsushima-Korea Straits. Journal of Geophysical Research 107, doi:10.1029/2000JC000702.

Jahnke, R.A., and G.A. Jackson. 1987. The role of seafloor organisms in oxygen consumption in the deep North Pacific Ocean. Nature 329:621-623.

Kang, D.-J., S. Park, Y.-G. Kim, K. Kim, and K.-R. Kim. 2003. A moving-boundary box model (MBBM) for oceans in change: Application to the East/Japan Sea. Geophysical Research Letters 30, doi:10.10129/2002GL016486.

Kim, K., and J.-Y. Chung. 1984. On the salinityminimum and dissolved oxygen-maximum layer in the East Sea (Sea of Japan). Pp. 55-65 in Ocean Hydrodynamics of the Japan and East China Seas, T. Ichiye, ed. Elsevier, New York.

Kim, K.-R., and K. Kim. 1996. What is happening in the East Sea (Japan Sea)?: Recent chemical observation during CREAMS 93-96. Journal of the Korean Society of Oceanography 31:164-172.

Kim, Y.-G., and K. Kim. 1999. Intermediate waters in the East/Japan Sea. Journal of Oceanography 55:123-132.

Kim, K., K.-R. Kim, J.-Y. Chung, B.-H. Choi, S.K. Byun, G.H. Hong, M. Takematsu, J.-H. Yoon, Y. Volkov, and M. Danchenkov. 1996. New findings from CREAMS observations: Water masses and eddies in the East Sea. Journal of the Korean Society of Oceanography 31:164-172.

Kim, K.-R., K. Kim, D.-J. Kang, S.-Y. Park, M.-K. Park, Y.-G. Kim, H.-S. Min, and D. Min. 1999. The East Sea (Japan Sea) in change: A story of dissolved oxygen. Marine Technology Society Journal 33:15-22.

Kim, K., K.-R. Kim, D.-H. Min, Y. Volkov, J.-H. Yoon, and M. Takematsu. 2001. Warming and structural changes in the East (Japan) Sea: A clue to future changes in global oceans? Geophysical Research Letters 28:3,293-3,296.

Kim, K.-R., G. Kim, K. Kim, L. Lobanov, V. Ponomarev, and A. Salyuk. 2002. A sudden bottom-water formation during the severe winter 2000-2001: The case of the East/Japan Sea. Geophysical Research Letters 29(8), doi:10.1029/ 2001 GL014498.

Kim, K., K.-R. Kim, Y.-G. Kim, Y.-K. Cho, D.-J. Kang, M. Takematsu, and Y. Volkov. 2004. Water masses and decadal variability in the East Sea (Sea of Japan). Progress in Oceanography 61:157-174.

Marshall, J., and F. Schott. 1999. Open-ocean convection: Observations, theory, and models. Reviews of Geophysics 37:1-64.
Min, D.-H., and M.J. Warner. 2005. Basin-wide circulation and ventilation study in the East Sea (Sea of Japan) using chlorofluorocarbon tracers. Deep-Sea Research II 52:1,580-1,616.

Mitchell, D.A., D.R. Watts, M. Wimbush, W.J. Teague, K.L. Tracey, J.W. Book, K.-I. Chang, J.-S. Suk, and J.-H. Yoon. 2005. Upper circulation patterns in the Ulleung Basin. Deep-Sea Research II 52:1,617-1,638.

Miyazaki, M. 1953. On the water masses of the Japan Sea. Bulletin of the Hokkaido Regional Fisheries Research Laboratory 7:1-65.

Mooers, C., I. Bang, and F.J. Sandoval. 2005. Comparisons between observations and numerical simulations of Japan (East) Sea flow and mass fields in 1999 through 2001. Deep-Sea Research II 52:1,639-1,661.

Postlethwaite, C.F, E.J. Rohling, W.J. Jenkins, and C.F. Walker. 2005. A tracer study of ventilation in the Japan/East Sea. Deep-Sea Research II 52:1,684-1,704.

Preller, R.H., and P.J. Hogan. 1998. Oceanography of the Sea of Okhotsk and the Japan/East Sea. Pp. 430-481 in The Sea, vol. 11, A.R. Robinson and K.H. Brink, eds. John Wiley and Sons, Inc., Hoboken, NJ.

Riser, S.C., and G. Jacobs. 2005. The Japan/East Sea: A historical and scientific introduction. DeepSea Research II 52:1,359-1,362.

Saunders, P., K-H. Mahrt, and R.T. Williams. 1994. Standards and laboratory calibration, WHP 911: WOCE Operations Manual. [Online] Available at: http://whpo.ucsd.edu/manuals.htm [last accessed August 9, 2006].

Senjyu, T., T. Aramaki, S. Otosaka, O. Togawa, M. Danchenkov, E. Karasev, and Y. Volkov. 2002. Renewal of the bottom water after the winter 2000-2001 may spin-up the thermohaline circulation in the Japan Sea. Geophysical Research Letters 29(7):1149, doi:10.1029/2001GL014093.

Senjyu, T., H.-R. Shin, J.-H. Yoon, Z. Nagano, H-S. An, S.-K. Byun, and C.-K. Lee. 2005. Deep flow field in the Japan/East Sea as deduced from direct current measurements. Deep-Sea Research II 52:1,726-1,741.

Senjyu, T., and H. Sudo. 1993. Water characteristics and circulation of the upper portion of the Japan Sea proper water. Journal of Marine Systems 4:349-362.

Senjyu, T., and H. Sudo. 1994. The upper portion of the Japan Sea Proper Water: Its source and circulation as deduced from isopycnal analysis. Journal of Oceanography 50:663-690.

Shcherbina, A., L.D. Talley, and D.L. Rudnick. 2003. Direct observations of brine rejection at the source of North Pacific Intermediate Water in the Okhotsk Sea. Science 302:1,952-1,955.

Shikama, N. 1994. Current measurements in the
Tsugaru Strait using bottom-mounted ADCPs. Kaiyo Monthly 26(12):815-818 (in Japanese).

Sudo, H. 1986. A note on the Japan Sea Proper Water. Progress in Oceanography 17:313-336.

Talley, L.D. 1991. An Okhotsk water anomaly: Implications for ventilation in the North Pacific. Deep-Sea Research 38 (Suppl. 1):S171-S190.

Talley, L.D. 2006. Hydrographic Atlas of the World Ocean Circulation Experiment (WOCE), vol.2: Pacific Ocean, M. Sparrow, P. Chapman and J. Gould, eds. International WOCE Project Office, Southampton, United Kingdom, in preparation.

Talley, L.D., V. Lobanov, V. Ponomarev, A. Salyuk, P. Tishchenko, I. Zhabin, and S. Riser. 2003. Deep convection and brine rejection in the Japan Sea. Geophysical Research Letters 30(4):1159, doi:10.1029/2002GL016451.

Talley, L.D., P. Tishchenko, V. Luchin, A. Nedashkovskiy, S. Sagalaev, D.-J. Kang, M. Warner, and D.-H. Min. 2004. Atlas of Japan (East) Sea hydrographic properties in summer, 1999. Progress in Oceanography 61(2-4):277-348, doi:10.1016/ j.pocean.2004.06.011. Note: supplementary materials [Online] available at: http://japanseaatlas.ucsd.edu [last accessed August 9, 2006].

Teague, W.J., P.A. Hwang, G.A. Jacobs, J.W. Book, and H.T. Perkins. 2005a. Transport variability across the Korea/Tsushima Strait and the Tsushima Island wake. Deep-Sea Research II 52:1,784-1,801.

Teague, W.J., K.L. Tracey, D.R. Watts, J.W. Book, K.I. Chang, P.J. Hogan, D.A. Mitchell, M.-S. Suk J. Wimbush, and J.-H. Yoon. 2005b. Observed deep circulation in the Ulleung Basin. Deep-Sea Research II 52:1,802-1,826.

Uda, M. 1934. The results of simultaneous oceanographical investigations in the Japan Sea and its adjacent waters in May and June, 1932. Journal of the Imperial Fisheries Experimental Station 5:57-190 (in Japanese with English abstract).

Vasiliev, A.S., and V.P. Makashin. 1992. Ventilation of the Japan Sea waters in winter. La Mer 30:169-177.

Warner, M.J., and G.I. Roden. 1995. Chlorofluorocarbon evidence for recent ventilation of the deep Bering Sea. Nature 373:409-412.

Watanabe, T., M. Hirai, and H. Yamada. 2001. High-salinity intermediate water of the Japan Sea in the eastern Japan Basin. Journal of Geophysical Research 106:11,437-11,450.

Yanagi, T. 2002. Water, salt, phosphorus and nitrogen budgets of the Japan Sea. Journal of Oceanography 58:797-804.

Yoshikawa, Y., T. Awaji, and K. Akitomo. 1999. Formation and circulation processes of intermediate water in the Japan Sea. Journal of Physical Oceanography 29:1,701-1,722. 